\title{
Ralph Thaxton
}

\section{China Turned Rightside Up. Revolutionary Legitimacy in the Peasant World}

Yale University Press, New Haven/London, 1983, 286 S., $\mathfrak{E} 22.50$

This is in many ways a passionate book. Its author explores the local conditions in rural China under which the Communist revolutionary movement could strike roots and thrive, surviving numerous, often sanguinary setbacks until it finally shattered and swept to the redoubt of Taiwan the disarrayed remnants of Generalissimo Jiang Kaishek's forces. The study is thus both about the human and political drama of social revolution in postimperial China and, by implication, about the primarily American debate on the causes of 'Free China'sı collapse in the face of Mao's armies.

An investigation into the political and military dégringolade of the Kuomintang régime leads necessarily to a survey of the welfare of Chinese peasants after the fall of the imperial state in 1911 and of the achievements of the Nationalist government after its consolidation, upon the completion of Jiang's Northern Expedition. The author's targets in the scholarly controversy involved are those, like Chalmers A. Johnson and Ramon H. Myers, ${ }^{1}$ who attempted to demonstrate that the medium-term development of the Chinese rural economy was basically favourable to small-holder peasants and that the exceptional conjunction of forces resulting from Japan's aggression against China and the ensuing Second World War provided the opportunity for a Communist victory on the mainland which 'normal circumstances' would not have permitted. Historiography in the U.S. thus appeared a prey of policies then prevailing and of the wider struggle for diplomatic supremacy between 'Red ' China and the KMT administration in Taiwan. ${ }^{2}$

Other Western scholars before Mr Thaxton have described the social conditions of oppression and spoliation by warlords, gentry and a Kuomintang which all too often contented itself to coalesce with the former two, without serious attempts at rural social reform. ${ }^{3}$ But this study focusses again, after other, less satisfactory attempts ${ }^{4}$ on the emergence of revolutionary potential in a particular area - the Shanxi-Hebei-Shandong-Henan border region, whither the Chinese Communists' core base had shifted after the Long March.

Mr Thaxton's line of argument sets out from the late Qing and the slow decay of the imperial polity which, although exploitative and a structure of domination by officials and gentry over the multitude of peasants, was still predicated on a functioning rural economy and geared to ensuring basic conditions of survival of its constituents. Gentry and the

1 Peasant Nationalism and Communist Power: The Emergence of Revolutionary China 1937-1945, Stanford: Stanford U Pr, 1962, and The Chinese Peasant Economy: Agricultural Development in Hopei and Shantung 1890-1949, Cambridge, Mass: HUP 1970, respectively.

2 Cf Jürgen Osterhammel, "Anfänge der chinesischen Revolution: Die zwanziger Jahre", in: NEUE POLITISCHE LITERATUR, xxvii/1 (1982), pp $84 \mathrm{ff}$.

3 The most powerful account, although limited to one locality, is perhaps still William Hinton, Fan Shen: A Documentary of Revolution in a Chinese Village, New York: Random House, 1966.

4 Eg, Roy Hofheinz, Jr. The Broken Wave. The Chinese Communist Peasant Movement, 1922-28, Cambridge, Mass: HUP, 1977. 
imperial state observed, or acquiesced to, minimal demands made by peasants in their relation to landlords and government. Remission of rent, taxes and corvée services were used by powerholders to accomodate the needs of peasants in times of crisis. With the demise of the imperial system and penetration of the local rural economy by monetarisation and cash-cropping induced by growing contacts with the world market, this paternalistic modus vivendi between peasants and the powerful came unstuck. The later regional strongmen, or warlords, were no longer committed to the preservation of the social fabric, as the imperial administration had been. Peasants, mostly but one step ahead of disaster in a cycle of production where one crop failure would spell famine and ruin, were thus forced to fight for survival against the pressure from gentry and warlords which was no longer reined in by the inherent checks of the old imperial system. Jiang's KMT depended on alliances with warlord rulers and, as concomitant concessions, often merely confirmed gentry and militarists in their rapaciousness towards the peasantry. The $\mathrm{Na}$ tionalist régime thus failed, by impotente, neglect or design, to remove from the rural poor the exploitation by strata no longer integrated into the agricultural economy.

In their struggle peasants absorbed and developed traditional religious images of emancipation and deliverance from their overlords, and it was this potential rather than the constellation of war and its consequences that the Chinese Communist Party accepted and utilised as a powerful factor to win the support of the rural masses. Mr Thaxton depicts the victory of Mao Zedong in 1949 not least as the vindication of these grass-roots aspirations grown out of an autochthonous revolt by the poor inspired by popular traditions against an exploitative superstructure cast loose from its commitment to the social whole.

The author had an opportunity to do some research in Henan in 1980 and provides much, often gruesome, detail of gentry and warlord excesses against an impoverished rural population. Nonetheless the bulk of his material still comes from secondary sources, and his numerous references to Chinese monographs often do not allow to gauge the weight and dimension of particular incidents quoted from them. Further study and evaluation of the Chinese sources will perhaps create a larger prespective for the Western reader in the future.

The language of the book is occasionally jargonised ("ideational inspiration", "mobilisational weapons", "retreatist self-help", "solidaristic counterculture"). At some points the discussion of broader concepts is cursory and nebulous, drawing on highly diverse sources, on peasant societies far apart in space and time, conjuring up an analytical foundation which may be more apparent than real. ${ }^{5}$ On the whole, however, the approach chosen by the author appears promising and it is to be hoped that more work, in particular by Chinese researchers on the mainland, will shed further light on the elemental dynamic which synenergised the revolution that gave birth to the People's Republic.

Wolfgang Kessler

Eg, the reference to Pitt-Rivers, $\mathrm{p} 3$; the topsy-turvy conclusions derived from Moore, $\mathrm{p} 13$. 